\title{
The influence of curriculum and school climate on the academic attitude of tahfiz students in Malaysia
}

\author{
Muhamad Suhaimi Taat, Roslee Talip, Musirin Mosin
}

Faculty of Psychology and Education, University Malaysia Sabah, Malaysia

\begin{tabular}{l} 
Article Info \\
\hline Article history: \\
Received Dec 7, 2020 \\
Revised Jun 14, 2021 \\
Accepted Jul 15, 2021 \\
\hline
\end{tabular}

Keywords:

Attitude

Curriculum

Memorizing Al-Quran

School climate

Tahfiz student

\begin{abstract}
This study aimed to examine the influence of curriculum and school climate on the academic attitude of tahfiz (memorizing Al-Quran) students in Sabah, Malaysia. A total of 81 students (age 10-12) from three private tahfiz primary schools around Kota Kinabalu were involved in this study. This quantitative study used cross-sectional survey method by distributing questionnaires to the respondents. The questionnaire was developed by the researchers to suit the unique environment of the tahfiz schools and has gone through the process of validity and reliability. Descriptive analysis showed that student attitude variable showed a high level of mean score (above 3.80), while for school climate variable, the finding was at moderate level (Mean=3.56, $\mathrm{SD}=0.530$ ). As for curriculum variable, most students learnt the same main subjects as studied in government-aided primary schools, with addition to Quranic subject. However, no one learnt Computer Education subject. Multiple regression analysis showed that only the school climate variable significantly influenced the academic attitude of tahfiz students $(\mathrm{R} 2=0.251$, Beta $=0.503, p<0.001)$. This study will be able to provide useful information and benefit for the improvement of tahfiz institutions in Malaysia.
\end{abstract}

This is an open access article under the $\underline{C C B Y-S A}$ license.

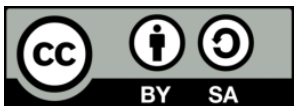

\section{Corresponding Author:}

Muhamad Suhaimi Taat

Faculty of Psychology and Education

University Malaysia Sabah

88400, Kota Kinabalu, Sabah, Malaysia

Email: suhaimi@ums.edu.my

\section{INTRODUCTION}

Tahfiz (memorizing Al-Quran) institution has grown rapidly in Malaysia over the past decade. Awareness of parents and the community regarding the importance of religious education and inspiration to produce a hafiz (person who memorize Al-Quran) in a family has encouraged the growth of tahfiz schools throughout the country, including in the state of Sabah. Yet the existence of so many tahfiz schools has invited various issues such as direction and objectives, quality of teaching and learning [1]-[3], the uniformity of the syllabus or learning modules and financial, as well as future problems of these students after they finished their study [4], [5]. Hence, the main purpose of this study was to identify the influence of the curriculum and school climate on the academic attitude of tahfiz students in Sabah, Malaysia. This study is very important because it is very relevant to the present scenario of tahfiz institutions in the country and among the earliest study pertaining the subject matters. This paper will explain more about the variables involved in this study, the methodology used, the finding, and later the discussion as well as the conclusion. 


\section{LITERATURE REVIEW}

The philosophy of education in Malaysia aims to produce balanced, harmonious and skilled human beings. The country's education system also gives students the freedom to choose the specific fields they are interested in, including the field of memorizing the Al-Quran. The tahfiz institution has become a new phenomenon and is growing rapidly in Malaysia over the past decade [6]. Parental concerns over the various social issues plaguing the country, especially adolescents and community awareness related to the importance of religious education and inspiration to produce a complete individual (hafiz, religious and academic) in one family have encouraged the establishment of private tahfiz schools in the country including the state of Sabah. However, the existence of many tahfiz schools have invited various issues and phenomena. Among the issues that are often raised are the actual direction and objective of the establishment of these tahfiz schools. Other than that, are the issues of the quality of teaching and learning implementation carried out in tahfiz schools as well as the quality of students produced. Even now there are quite a few tahfiz graduates who seem to find it difficult to compete for jobs that are suitable for their field which only specializes in memorizing the Al-Quran without having other skills. Most of the tahfiz schools that exist, especially in Sabah, do not have a standardized syllabus or learning modules. This is compounded by various problems or constraints faced such as financial problems to cover the expenses of managing and maintaining tahfiz schools. The heartbreaking incident of several tahfiz schools has also opened the eyes of various parties regarding the issue of security and health as well as infrastructure equipment in tahfiz schools. As mentioned earlier, most of the tahfiz schools also had funding problems to cover the operation of the school and had to ask for public donations to finance the expenses of managing and maintaining their respective schools.

However, despite the various problems that arose, tahfiz school still received encouraging response from parents. Thus, several studies have been conducted by several researchers in the country to look at this phenomenon. Among them was a study by Nawi, et al. [1] and Bani, et al. [2] which found that the direction and goals of tahfiz schools are still unclear. Furthermore, Ismail, et al. [5] explained that the role of administrator, teaching and learning process and good strategies in excellent tahfiz educational institutions need to be refined. This is important to be a guideline for tahfiz educational institutions in Malaysia to strengthen the excellence of tahfiz Al-Quran diploma students. Tahfiz schools were also found with no standardized requirements in terms of student selection for admission to their respective schools [4], [7]. The absence of a standardized appointment scheme for the teachers had also been a constraint factor [8]. Moreover, the study by Ghani, et al. [9] found that most of these tahfiz schools have different objectives, approaches, and management. However, there has not been an integrated and in-depth study that examines the basic things related to tahfiz institutions such as the basic factors that lead to the establishment of tahfiz institutions and looking at important aspects of students such as academic attitude and so on. Therefore, this preliminary survey study on the influence of curriculum and school climate on the academic attitude of tahfiz students in Sabah was relevant because the data gathered and analyzed were able to provide additional information on issues and problems. The data were based on empirical evidence collected using the research instruments of high validity and reliability, rather than mere personal views or assumptions.

\subsection{Curriculum}

Curriculum is the combination of instructional practices, learning experiences, and students' performance assessment that are designed to bring out and evaluate the target learning outcomes of a course. Curriculum is also a learning plan, which is closely related to the documents used as a starting point in teaching planning, whether formal or informal, real or hidden [10], [11] According to Ahid [12], from the perspective of Islamic Education, curriculum is referred to the word 'manhaj' in Arabic word which means the bright path that human beings need to go through in various areas of life. While, Siraj [13] stated that manhaj in the field of education refers to the clear path traversed by educators along with people who are educated or trained to develop their knowledge, attitudes, and skills.

According to Ahid [12], this manhaj is closely related to the Tyler curriculum model which was known as a direct or indirect curriculum model. Tyler's model outlines curriculum development approaches through basic curriculum and instructional principles. According to Ornstein and Hunkins [14], the Tyler model proposed four ways or steps to build a curriculum namely determining educational purpose, determining educational experience related to educational purpose, determining, or organizing educational experience effectively, and determining educational experience evaluation.

Among the most popular curriculum models for tahfiz institution in this country is the Ulul Albab model. According to Arshad [15], the Ulul Albab model emphasized the approach of three important elements namely quranic, ijtihadik and encyclopedic. These three elements are used as the fundamental elements in the development of the Tahfiz Model Ulul Albab curriculum in Malaysia. This model is suitable because of the Ulul Albab elements that suits the needs of religious students. According to Rohaizan, Zulkifli, and Hakim [16], Quranic refers to the student's ability to memorize 30 verses of the Al-Quran and 
applying the Quranic teachings in daily life. Ijtihadik is the ability to contribute ideas, solve problems and innovate creativity by using the Quranic wisdom. Finally, encyclopedic is referred to the ability to become an expert in various fields of knowledge and language.

A study by Daud, Adi, and Abdullah [17] on the evaluation of the implementation of qiraat curriculum in Darul Quran and tahfiz Al-Quran schools in Malaysia, showed that the evaluation of qiraat curriculum that is the relevance of qiraat curriculum and self-assessment of lecturers was at a high level. On the other hand, for students' self-assessment of the qiraat curriculum, that was, the content of the qiraat curriculum, including the allocation of teaching and learning time as well as the facilities of teaching aids were at a moderate level. As for the findings of the qiraat curriculum evaluation, it showed the qiraat knowledge method and practical method were at a high level, but the use of teaching aids, particularly ICT was at a low level. Based on the findings of the study, it was suggested that the implementation of teaching and learning of qiraat curriculum as well as further enhance the mastery of qiraat students in tahfiz educational institutions throughout Malaysia. In addition, the study of Aziz [18] showed that the level of curriculum management and planning was at high level with mean scores of 4.10 and 4.13. Furthermore, ANOVA analysis showed no significant differences in the planning and management aspects based on the teachers' teaching experience. According to Tao [19], curriculum design and development is very crucial to ensure the successful of a program. Among the obstacles that were identified in implementing the curriculum were teacher workload and student factors as well as administrative and facilities constraints. Several studies also emphasized on the importance of updated curriculum and to reform the curriculum to stay relevant with the necessity and demand of the country [20].

\subsection{School climate}

School climate or environment means the extent to which the school implements and guarantees student safety and health, which may include various aspects such as physical growth, academic environment, physical and mental health support and services available, as well as the appropriateness and adequacy of disciplinary [21]. According to Rozario and Taat [22], school climate is the result of interpersonal relationships formed among students, teachers, families, administrators and school support staff. In addition, the school climate also includes the academic elements, community, safety and dimensions of the school environment which covers almost every feature of the school environment that influences behavior, cognitive and developmental psychology [23]. Operationally defined school climate as an asset that can measure the work environment based on the collective perception of people working in the environment which can influence their behavior. This shows that how people perceive school climate and the tasks related to the environment will influence the formation of the behavior of its members [24]. Awang, et al. [25] the review, have emphasized on the supportive physical learning ecosystem and encouraging environment to enhance the quality of education at tahfiz institutions.

The theory that can empirically illustrate the principles of school climate is Allardt Sociological Welfare Theory [26]. This theory described the welfare system which consists of two main indicators, namely objective and subjective indicators. Each of these indicators has its own measurement characteristics. Welfare in this theory is also meant as well-being that covers the level and quality of life. Well-being is referred as a condition of the possibility of whether man is satisfied with the basic needs he already has. Allardt's Sociological Welfare Theory is also divided into three main categories. First is the possession that refers to personal and material needs. The second category is love which refers to social needs including the formation of social relationships with people in the environment. The third category is humanity, which is the need for individual self-development. Based on Allardt's Theory of Sociology, the school climate can be referenced based on the categories and theoretical indicators in each of its descriptions.

A study by Fakhruddin, et al. [27] who had studied 28 risky schools in the states of Selangor and Kuala Lumpur found that the learning climate in the classroom was moderate. Furthermore, the findings also showed that there were significant differences in student's perceptions of teachers' expectations, teachers' teaching and teachers' concern. In addition, the findings of the study found that smart students have a more positive perspective on these three aspects compared to the moderate and weak students. Besides that, a study by Noor, Omar, and Hussin [28] showed a moderate level of school climate level and job satisfaction of teachers in secondary schools. Furthermore, there was a strong positive relationship between teachers' job satisfaction with school climate. Therefore, it is obvious that school climate is one of the most important aspects that will influence the teaching and learning effectiveness [29]. Besides that, a study by Hassanuddin, et al. [30] found that school climate was significantly contributed to the academic achievement of the students. Apart from teacher's teaching strategy and school leadership, school environment or climate can really affect student's performance [31], [32]. 


\subsection{Student academic attitude}

Attitude is a mental and neural state of readiness, organized through experience, exerting a directive and dynamic influence upon the individual's response to all objects and situations with which it is [33]. Thus, attitude can be inferred as a ready-made mental readiness resulting from experiences that then influence a person to respond to an object or a situation. According to Mahyuddin and Elias [34], attitude is the character of an individual in acting to a certain degree as an attraction or vice versa to the object, person, event or any aspect of discrimination based on the individual situation. Allport [33] who was one of the early researchers on attitude had stated that there were three main characteristics in the theory of attitude namely readiness, learned attitudes and dynamic nature. A characteristic of readiness is how a person sees objects or people around them in a certain way. Both attitudes are learnt in the environment and not inherited. The three dynamic properties possessed will influence anybody to do something or avoiding it. All these characteristics are the attitude theory pioneered by Allport as the basis of the attitude theory he introduced. Each characteristic of Allport's attitude theory also showed its own concept but served as a unit of attitude. Taat, Abdulbaki, and Al-Saqqaf [35] found that positive interaction between the teachers with the students will foster high level of academic attitude among the students. Therefore, attitudes as part of an individual's personality is as a result of behavioral influences which are related to the individual himself.

According to Ashmad [36] in her study on the influence of teachers' teaching and students' academic attitudes towards High Order Thinking Skills (HOTS) found that students' perceptions of teachers' teaching were at a good level. Besides, the relationship of students' academic attitudes with HOTS showed that there was a strong positive correlation. Furthermore, the study also found that academic attitudes affect Kemahiran Berfikir Aras Tinggi (KBAT) significantly. The study by Nasir and Hamzah [37] about attitude and motivation of students towards learning English showed $78 \%$ of the total sample had a positive academic attitude. The findings showed a positive attitude of most of the respondents to the Malay language was due to the teachers' effort in helping their students to do assignments. Further study by Iberahim, Mahamod, and Mohammad [38], showed the level of students' attitudes to learn the Malay language as applied skills of the 21st century was at a very high level. A study by Taat and Abdullah [39] found that there was a significant correlation between student academic attitude with the teaching process and guidance from the teachers. Student academic attitude is also influenced by their perception of the school climate [40].

\section{RESEARCH METHOD}

\subsection{Research design}

This study used a survey method which applied the quantitative approach to collect the data. A set of close questionnaires was used as the research instrument. The questionnaire items were constructed and developed the researchers consisting of those who are experts in this field of study, with referred to existing theories and models, adapted to the respondents. Questionnaire for school climate and academic attitude variables used a 5-point Likert scale (1=Strongly Disagree, 2=Disagree, 3=Not Sure, 4=Agree, 5=Strongly Agree). While for curriculum variables, researchers collected the data related to the subjects taught in their school involving core and elective subjects that there are 24 subjects learnt whether they were taught or not in school (Taught=1, Not Taught=0), which will bring a total score of 24 if all the subjects were taught in school. The subjects are Malay Language, English, Arabic, Mathematics, Science, Islamic Studies, Education Quran, Computer Education, Health and Physical Education, Science, Morals, Fiqh, Hadith, Dictation, History, Recitation, Tauhid, Tafsir, Khat, Chinese, Worship, Quranic Recitation, Jawi, and Faith. Then the questionnaire underwent a process of validity and reliability to ensure that the items can measure what should be measured. The study sample was 81 level 2 primary school pupils (10-12 years old) in three tahfiz primary schools around Kota Kinabalu district, out of 160 population. These schools were chosen because they are among the top schools and have a large number of students. The number of samples was enough to perform descriptive and inference analysis [41]. These quantitative data were analyzed descriptively and inferences (mean score/standard deviation, and multiple regression). The measure for the school climate and academic attitude variable was the mean score, while for the curriculum variable, the overall score was used. Both types of scores are continuous data that allow descriptive and inference analysis to be conducted.

\subsection{Construct validity (Factor analysis)}

To ensure that the items for all variables have high construct validity and measure the variables that should be measured, exploratory factor analysis (EFA) was conducted on the items based on the variables. The analysis has found that all items for the School Climate and Academic Attitude variables were retained because of the loading factor for each item exceeding 0.40 [42] as shown in Table 1 and Table 2. For curriculum variable, construct validity has been validated because all the subjects taught are subjects that should be taught in government-aided primary schools, as well as tahfiz and religious subjects. 
Table 1. Factor analysis for school climate

\begin{tabular}{lc}
\hline \multicolumn{1}{c}{ Questionnaire items } & Loading factors \\
\hline My class is equipped with teaching and learning facilities & -.548 \\
My class environment motivated me to learn & .498 \\
There are too many pupils in my class (crowded) & .461 \\
My school surroundings are clean & .597 \\
My school surroundings are cheerful & .742 \\
My class teacher cares about me & .646 \\
My class teacher gives me the opportunity to discuss any problems & .586 \\
My class teacher always motivates me & .748 \\
My class teacher's relationship with me was warm & .563 \\
I trust my friends at school & .490 \\
My friend and I discussed a lot about lessons during school & .601 \\
My friend cares about me & .545 \\
\hline
\end{tabular}

Table 2. Factor analysis for student academic attitude

\begin{tabular}{lc}
\hline \multicolumn{1}{c}{ Questionnaire items } & Loading factors \\
\hline The number of subjects taught did not burden me & -.517 \\
The syllabus here suits my interest & .774 \\
The contents of the Quranic subjects are easy to understand. & .760 \\
I can follow the method or technique of teaching for Al-Quran memorization & .818 \\
I am really interested in studying at this school & .734 \\
I love studying the Al-Quran & .788 \\
I like to deepen my knowledge of the Al-Quran & .784 \\
I want to memorize the whole Al-Quran (Hafiz) & .717 \\
Academic subjects (such as Science, Mathematics and English) are not important to me & .572 \\
I prefer religious subjects/Al-Quran than academic subjects & .736 \\
After graduating from this school, I will continue my studies in the field of religion & .574 \\
After memorizing the entire Al-Quran (Hafiz), I want to continue my study in other academic & .892 \\
fields (such as medicine, engineering, arts, and economics) &
\end{tabular}

\subsection{Internal validity (Reliability)}

Table 3 showed the reliability analysis. The reliability analysis showed that all the research variables indicated an acceptable and good reliability values. The accepted values for Cronbach alpha are 0.60 and above.

Table 3. Variables' reliability

\begin{tabular}{ccc}
\hline Variables & Cronbach alpha & Number of items \\
\hline School climate & .775 & 12 \\
Student's academic attitude & .807 & 12 \\
Curriculum & .701 & 24 \\
\hline
\end{tabular}

\section{RESULTS}

\subsection{Descriptive analysis}

Based on Table 4, the findings showed that overall, the academic attitude variable showed a high mean score value/good/positive because it exceeds the mean score value of 3.80 . While the school climate variable showed a moderate level (Mean=3.56, $\mathrm{SD}=0.530)$. As for curriculum variables, the finding showed that the mean score for the curriculum is 15 ( $\mathrm{SP}=3.61)$ which was at a moderate level too. In addition, the study showed that all students took subjects of Malay Language, English, Arabic, Mathematics, Science, Education Islam, Quran Education and Health Physical Education. Meanwhile, no students took the subject of Computer Education. There is a school that teaches Chinese subjects for their students. For the rest of the subjects, not all respondents learnt them at their respective schools.

Table 4. Variables' descriptive analysis

\begin{tabular}{cccc}
\hline Variables & $\mathrm{N}$ & Mean & SD \\
\hline School climate & 81 & 3.567 & .530 \\
Student academic attitude & 81 & 3.869 & .532 \\
Curriculum & 81 & 15.00 & 3.61 \\
\hline
\end{tabular}


For school climate variable, the mean score was at a moderate level. Among the items that showed the highest mean score were 'My classroom is equipped with teaching and learning facilities' (4.00), 'My school area is cheerful' (3.96), and 'My school area is clean' (3.65). While among the items that showed a low mean, score was 'My friends and I talked a lot about lessons while at school' (3.33), 'My friends care about me' (3.49), and 'I trust my friends at school' (3.46). From the findings, the mean scores for item related to facilities and physical condition of the classroom was at a satisfactory level, while the relationship between respondents and their peers was at a moderate level, especially related to discussions with peers about lessons in school. As for the items for students' academic attitude variables, it shows that almost all items show a high mean score $(>3.80)$. This situation explained that the academic attitude of the students was very positive, and they seemed to be able to balance between tahfiz/religious subjects and academic subjects. Among the items that showed a high mean score were 'I want to memorize the whole Quran (Hafiz)' (4.52), 'I like to study the Quran' (4.35), and 'I am really interested in studying at this school' (4.30). In fact, they also wanted to continue their studies either in the field of tahfiz/religion or other fields after graduating from the tahfiz school.

\subsection{Inferential analysis}

Before parametric inference analysis (multiple regression) can be performed, the distribution of data must be analyzed to check the normality. Normality tests showed that all variables were normally distributed. This was indicated by the skewness and kurtosis values which range from -1 to 1 as shown in the Table 5 . Therefore, parametric inferential analysis (multiple regression) was performed.

\begin{tabular}{ccc}
\multicolumn{3}{c}{ Table 5. Variables' normality analysis } \\
\hline Variables & Aspect & Score \\
\hline \multirow{3}{*}{ School climate } & Mean & 3.68 \\
& Standard deviation & .529 \\
& Skewness & .144 \\
& Kurtosis & -.254 \\
Student academic attitude & Mean & 3.86 \\
& Standard deviation & .532 \\
& Skewness & -.579 \\
Curriculum & Kurtosis & .546 \\
& Mean & 15.00 \\
& Standard deviation & 3.61 \\
& Skewness & -1.083 \\
& Kurtosis & -.796 \\
\hline
\end{tabular}

To examine the effect of independent variables (predictors) on dependent variables (criteria), multiple regression analysis was performed. Referring to Table 6, the finding showed that only the school climate as predictor variable significantly influenced students' academic attitude as criterion variable with a value of $\mathrm{R}^{2}=0.251, \mathrm{p}<0.05$. This finding explained that the school climate is a major predictor that contributed $25.1 \%$ to changes in criterion variable (Student academic attitude).

Table 6. Regression analysis

\begin{tabular}{cccccc}
\hline Variable & $\mathrm{R}^{2}$ & $\beta$ & Beta & $\mathrm{t}$ & $\mathrm{p}$ \\
\hline School climate & .251 & .503 & .501 & 5.140 & 0.001 \\
\hline
\end{tabular}

\section{DISCUSSION}

Based on the descriptive data analysis that has been conducted, it was found that for the curriculum variable, which was the subjects taught in tahfiz schools, were the same except there was a school that teaches Chinese Language subject. This was a good thing and should be emulated by other schools. Besides learning Malay, English, and Arabic, they should also be exposed to other languages that can help them in the future. So, in general, the tahfiz schools were still relevant because implementing quite a comprehensive curriculum. This finding was in line with the study by Daud, Adi, and Abdullah [17], which showed that the evaluation of qiraat curriculum that was relevance of qiraat curriculum, and self-assessment of lecturers were at a high level. However, this study found that none of the schools taught Computer Education subject to their students. This finding supported the study by Daud, Adi, and Abdullah [17] which found that the use of teaching aids particularly ICT was at low level. During this era of Industrial Revolution 4 (IR4), students need to be exposed and equipped with technology-related knowledge so that they will not be left behind in 
the digital era now and in the future [43]. Several previous studies had found that there was no uniformity of syllabus or learning modules, as well as future problems of these students after their graduation [4], [5]. Moreover, the study by Ghani, et al. [9] found that most of these tahfiz schools had different objectives, approaches and management style. As for the school climate variables, it was found to be at a moderate level. These findings explained that students perceived that the atmosphere in their school either physically (infrastructure) and aspects of interaction can still be improved and need to be given more attention. Among the things that need to be improved are the interaction among the students in the classroom and the physical atmosphere of the classroom. The findings of this study were in line with the study by Stringer [24] who found that the learning climate in the classroom is at a moderate level. Furthermore, the findings also showed that there were significant differences in student's perceptions of teachers' expectations, teachers' teaching and teachers' concern. In addition, the findings of the study found that smart students had a more positive perspective on these three aspects compared to the moderate and weak students. In addition, a study by Awang, et al. [25] showed a moderate level of school climate and job satisfaction of teachers in secondary schools. Besides that, in this study, the student's academic attitude variables are at a high (good) level. This means, in general, students who study in tahfiz school are seriously wanted to achieve the ambition to become a 'Hafiz' as well as want to succeed in academics. The findings of this study were supported by a study by Rudasill, et al. [29] who found that students' academic attitudes and their perceptions of teacher's teaching were at a good level. A study by Hassanuddin, et al. [30] also showed that $78 \%$ of the respondents had a positive academic attitude. Furthermore, the study by Alhosani, Singh, and Nahyan [31] showed the level of students' attitudes to learn the Malay language as applied skills of the 21 st century was at a very high level.

To determine the influence of curriculum and school climate variables on students' academic attitudes, the findings showed that only school climate variable affect the academic attitudes, while curriculum variable had no influence on students' academic attitudes. These findings proved that the school climate was the only predictor that brought about a change in students' academic attitudes. This means that when the school climate is comfortable, good, and encouraging, then the academic attitude of the students will also be positive. On the other hand, when the school climate is uncomfortable and less encouraging, then the academic attitude of students will also be less positive or can be negative. The findings of this study were in line with the study by Awang, et al. [25] who found that there was a strong positive relationship between school climate and teacher's satisfaction. In addition, the findings of this study were in line with Allardt's Theory of Sociological Welfare which explained that when human needs can be met, then his attitude will also be changed to be more positive. Apart from that, teachers are also urged to use different teaching methods as well as good communication skills [44]. Therefore, the school management and teachers also need to manage the school, especially the classroom as best as possible, which is to ensure that the classroom is in a clean and comfortable condition, while emphasizing activities that involve interaction between students. Teachers need to diversify the processes, steps and activities of teaching and learning, especially student-centered strategy so that students can have better interaction and discussion with each other. This situation will be able to help to build and develop students' more positive and dynamic academic attitudes, which will eventually be able to affect their academic achievement and commitment [45]. Based on this study, we cannot deny the importance of appropriate curriculum and school climate that can support students' learning. This is important to ensure that the quality of education in tahfiz institutions will be optimized.

\section{CONCLUSION}

This study was conducted to identify the influence of curriculum and school climate on the academic attitude of tahfiz school students. Objectives, questions, and research hypotheses have been achieved and answered through valid and reliable research instruments. Data analyses used were also appropriate to the type of data and research questions to be answered through appropriate analysis. It can be concluded that the students in tahfiz school had a good and positive academic attitude and are really interested and want to be a memorizer of the Qur'an, without forgetting the academic field that for them is also important for their future. However, these students argued that aspects of the school climate need to be given more attention and improved, so that a more comfortable, harmonious, and stimulating learning environment can be created. Therefore, it is not surprising that school climate variable was the only variable that affect students' academic attitude. Despite of this small-scale study, the findings are able to provide useful input to be a reference and pave the way for further research for the sustainability of tahfiz institutions in our country especially in facing the 21 st century education challenges. Furthermore, National Tahfiz Council of Malaysia will refer the findings and other similar studies as well, to enhance the quality of the tahfiz institutions in the country. 


\section{ACKNOWLEDGEMENTS}

This study was conducted under the university research grant scheme (SBK0437-2018). Therefore, we want to thank the Centre of Research and Innovation for the grant which enables us to conduct this research and publish this paper.

\section{REFERENCES}

[1] N. H. Md Nawi, N. A. Yusuff, M. B. C. Yaacob, and N. H. Salleh, "Matlamat dan Halatuju Sistem Pengajian Tahfiz di Kelantan: Satu Pengamatan Awal," Prosiding 4th International Conference and Exhibition on Islamic Education (ICIEd 2014), 2014, pp. 1-15.

[2] H. Bani, M. Y. Jaafar, M. Katan, and A. H. M Noor, "An Overview of Governance and Accountability of Tahfiz Institutions in Malaysia: Religious Councils Perspective," SHS Web of Conferences, 2017, pp. 1-12.

[3] A. R. Abd Ghani and A. Hashim, "Persepsi Guru Tahfiz al-Quran Terhadap Kemudahan Infrastruktur Institusi Tahfiz Persendirian di Negeri Selangor,” Jurnal Kemanusiaan, vol. 16 no. 1, pp. 1-6, 2018.

[4] N. C. Hassan, F. M. Fakhruddin, A. F. M. Ayub, L. A. Mutalib, and W. M. W. Jaafar, "Tahfiz schools entry requirement and characteristics of tahfiz students" International E-Journal of Advances in Education, vol. 1, no. 3, pp. 234-244, 2015.

[5] M. J. Ismail, S. Mohamad, T. I. Puji, and N. H. Yusof, "Strategy of Tahfiz Al-Quran Excellence in Malaysia: A Literature Survey,” Jurnal Islam dan Masyarakat Kontemporari, vol. 15, no. 1, pp. 51-60, 2017.

[6] J. Apak, M. S. Taat, and N. M. Suki, "Measuring Teacher Creativity-Nurturing Behavior and Readiness for $21^{\text {st }}$ Century Classroom Management," International Journal of Information and Communication Technology Education (IJICTE), vol. 17, no.3, pp. 52-67, 2021.

[7] N. H. M. Nawi and N. H. Salleh, "Pembinaan Model Pengajian Tahfiz di Malaysia," The Online Journal of Islamic Education, vol. 5, no. 1, pp. 1-11, 2017.

[8] A. Hashim, M. M. A. Rahim, W. H. Abdullah, "Role of Employers in Empowering Lecturers in Tahfiz Institutions of Malaysia," Global Journal Al-Thaqafah GJAT, vol. 6, no. 1, pp. 13-21, 2016.

[9] A. R. Abd Ghani, M. K. Soroni, N. M. Haridi, Z. Daud, A. Hashim, and W. S. Yusoff, "Tahap Pengurusan Institusi Tahfiz Persendirian di negeri Selangor," Jurnal Penyelidikan Pendidikan dan Pengajian Islam, vol. 1, pp. 242-280, 2012.

[10] W. Pinar, W. Reynolds, P. Slattery, and P. Taubman, "Chapter 1: Understanding Curriculum: An Introduction," Counterpoints, vol. 17, pp. 3-65, 1995. [Online]. Available: http://www.jstor.org/stable/42974917.

[11] A. Kelly, The Curriculum: Theory and Practice, 6th Ed. New York: Sage Publication, 2009.

[12] N. Ahid, "Curriculum concepts and theories in education," (in Bahasa), ISLAMICA, vol. 1, no. 1, pp. 12-29, 2006.

[13] S. Siraj, Kurikulum Masa Depan. Kuala Lumpur: Universiti Malaya, 2008.

[14] A. Ornstein and F. Hunkins, Curriculum Design. In Curriculum: Foundations, Principles and Issues, 5th Ed. Boston, MA: Pearson/Allyn and Bacon, 2009.

[15] A. M. Arshad, "Ulasan Sistematik: Program Ulul Albab Dalam Sistem Pendidikan Di Malaysia," JuKu: Jurnal Kurikulum \& Pengajaran Asia Pasifik, vol. 3, no. 4, pp. 22-35, 2015.

[16] B. Rohaizan, A. Zulkifli, and A. Hakim, "Showcasing an Alternative Educational Systems Using the Philosophy of Ulul Albab," Swiss Journal of Research in Business and Social Sciences, vol. 1, no. 1, pp. 1-10, 2014.

[17] Z. Daud, M. F. A. Adi, and M. Abdullah, "Kaedah pengajaran dan pembelajaran pengajian qiraat di Jabatan AlQuran dan Al-Qiraat, KUIS: Satu tinjauan awal," International Conference on Research in Islamic and Arabic Language Education 2012, Mecca, Saudi Arabia, Jun. 2012.

[18] W. E. W. Aziz, "Pelaksanaan Pengurusan Kurikulum Dalam Kalangan Guru-Guru Sekolah Menengah Kluster Daerah Johor Bahru,” Thesis, UTM, 2014.

[19] Y. Tao, "Design, development and evaluation of academic oral English curriculum reform," Theory and Practice in Language Studies, vol. 7, no. 6, pp. 427-435, 2017.

[20] M. P. Lyndon, M. A. Henning, H. Alyami, A. Krishna, T.C. Yu, and A.G. Hill, "The Impact of a Revised Curriculum on Academic Motivation, Burnout, and Quality of Life Among Medical Students," Journal of Medical Education and Curricular Development, vol. 4, pp. 1-8, 2017.

[21] A.S. A. Lawrence and A. Vimala, "School Environment and Academic Achievement of Standard IX Students," Journal of Educational and Instructional Studies in The World, vol. 2, no. 3, pp. 210-215, 2012.

[22] G. R. Rozario and M. S. Taat, "The Influence of Learning Environment and Academic Self-Efficacy Towards Mathematics Achievement in Masterskill Global College, Malaysia," International Journal of Arts and Commerce, vol. 4, no. 2, pp. 43-52, 2015.

[23] M.T. Wang and J. Degol, "Climate: A Review of the Construct, Measurement, and Impact on Student Outcomes," Educational Psychology Review, vol. 28, no. 2, pp. 315-352, 2016.

[24] R. Stringer, Leadership and organizational climate. Upper Saddle River, NJ: Prentice-Hall, 2002.

[25] A. H. Awang, N. Ab Jalil, N. H. Salleh, H. Ab Jalil, and S. S. Salim, "Physical learning ecosystem and built environment of tahfiz institutions in Malaysia: a systematic review," Journal of Architecture, Planning and Construction Management, vol. 9, no. 1, pp. 98-103 2019.

[26] M.A. Raihan and M.T.K. Shukri, "Kemenjadian Pelajar Berasaskan Strategi Dan Pelaksanaan Iklim Dini: Satu Konseptualisasi," Asian People Journal (APJ), vol. 2, no. 1, pp. 54-63, 2019. 
[27] F. M. Fakhruddin, A. F. M. Ayub, N. C. Hassan, W. M. W. Jaafar, and L. A. Mutalib, "Learning Challenges and support Needed by Tahfiz Students at Selected Government - Funded Religious Schools in Malaysia," Journal of Quran Sunnah Education and Special Needs, vol. 3, no. 2, pp. 35-45, 2019.

[28] M. F. M. Noor, M. S. Omar, F. Hussin, "Hubungan Iklim Sekolah Dan Stres Guru Sekolah Menengah di Daerah Kuala Nerus, Terengganu," Proceeding of ICECRS, International Seminar on Generating Knowledge Through Research, UUM-UMSIDA, 2016, pp. 39-48.

[29] K. M. Rudasill, K. E. Snyder, H. Levinson, and J. L. Adelson, "Systems view of school climate: a theoretical framework for research," Educ Psychol Rev., vol. 30, pp. 35-60, 2018, doi: 10.1007/s10648-017-9401-y.

[30] H. Hassanuddin, et al., "Modeling the social, economic and environmental effects of Pondok Tahfiz," Management Science Letters, vol. 10, no. 9, pp. 1915-1922, 2020.

[31] A. A. Alhosani, S. K. Singh, and M. T. A Nahyan, "Role of school leadership and climate in student achievement. The mediating role of parental involvement," International Journal of Educational Management, vol. 31, no. 6, pp. 843-851, 2017.

[32] A. Hashim, "Correlation between Strategy of Tahfiz Learning Styles and Students Performance in Al-Qur'an Memorization (Hifz)," Mediterranean Journal of Social Sciences, vol. 6, no. 2, pp. 85-92, 2015.

[33] G. W. Allport, Pattern and growth in personality. Holt, Reinhart \& Winston. 1961.

[34] R. Mahyuddin and H. Elias, Psikologi Pendidikan untuk Perguruan. Shah Alam: Karisma Publications Sdn Bhd. 2002.

[35] M. S. Taat, K. Abdulbaki, and A. Al-Saqqaf, "The impact of lecture and interactive methods on student's English competency," International Journal of Emerging Technology in Learning, vol. 12, no. 20, pp. 255-267, 2020.

[36] T. A. Ashmad, "Pengaruh pengajaran guru dan sikap akademik pelajar terhadap KBAT (Kemahiran Berfikir Aras Tinggi) dalam mata pelajaran sejarah tingkatan empat," Thesis, Universiti Malaysia Sabah, 2018.

[37] Z. M. Nasir and Z. A. Z. Hamzah, "Sikap Dan Motivasi Pelajar Terhadap Pembelajaran Bahasa Melayu," Procedia-Social and Behavioral Sciences, vol. 134, pp. 408-415, 2014.

[38] A. R. Iberahim, Z. Mahamod, and W. M. R. W. Mohammad, "Pembelajaran abad ke-21 dan pengaruhnya terhadap sikap, motivasi dan pencapaian Bahasa Melayu pelajar sekolah menengah," Jurnal Pendidikan Bahasa Melayu; Malay Language Education (MyLEJ), vol. 7, no. 2, pp. 77-88, 2017.

[39] M.S. Taat and M.Y. Abdullah, "Impak pengajaran dan bimbingan guru Pendidikan Islam terhadap motivasi dan pembelajaran terarah kendiri pelajar," Jurnal Pemikir Pendidikan, vol. 5, pp. 1-17, 2014.

[40] N. Fatou and V. Kubiszewski, "Are perceived school climate dimensions predictive of students' engagement?" Soc. Psychol. Educ. vol. 21, pp. 427-446, 2018.

[41] A. S. Singh and M. B. Masuku, "Sampling Techniques and Determination of Sample Size in Applied Statistics Research: An Overview," International Journal of Economics, Commerce and Management, vol. 2 no. 11, pp. 1-22, 2014.

[42] J. F. Hair, W. C. Black, B. J. Babin, and R. E. Anderson, Multivariate Data Analysis, 7th ed. Prentice Hall, Englewood Cliffs: NJ, 2010.

[43] M. S. Taat and A. Francis, "Factors Influencing the Students' Acceptance of E-Learning at Teacher Education Institute: An Exploratory Study in Malaysia," International Journal of Higher Education, vol. 9, no. 1, pp. 133-141, 2020.

[44] K. Abdulbaki, M. Suhaimi, A. al-Saqqaf, and A. Jawad, "The Use of the Discussion Method at University: Enhancement of Teaching and Learning," International Journal of Higher Education, vol. 7, no. 6, pp. 118-128, 2018.

[45] E. F. Charlie, M. S. Taat, and F.H. Saikim, "Students' Interpretation and Commitment of Conservation Contents Based on School Context," Advanced Science Letters, vol. 23, no. 4, pp. 2704-2708, 2017. 